\title{
Expected Crop Yield Loss When Converting to Organic Dairy Farming in Denmark
}

\author{
N. Halberg and I. Sillebak Kristensen
}

\author{
National Institute of Animal Science, Foulum, P.O. Box 39, DK-8830 \\ Tjele, Denmark
}

\section{ABSTRACT}

Knowledge of differences between organic and conventional crop yields is of interest for farmers, advisors, politicians, and research scientists. Based on collected data from Danish organic and conventional mixed dairy farms the yield difference was estimated to be $21-37 \%$ in grain crops and $12-18 \%$ in fodder beets and grass/clover depending on climatic conditions and soil type. A method is presented to correct for the influence of year and geographic differences using crop and farmspecific simulated potential yields as regression variables in a linear statistical model. An interaction between potential yield and farming system indicates that other growth factors, possibly nutrients, are limiting the yields on organic farms more than on conventional farms. The results might facilitate modelling and evaluation of economics and energetics of organic farming at the crop and farm level.

\section{INTRODUCTION}

Farmers, advisors, research scientists, and politicians request estimates of the crop yield loss when converting to organic agriculture. A limited number of comparisons between organic and conventional crop production have been reported, but most often the problems of generalization across years and soil types have not been thoroughly discussed (for recent reviews see Wagstaff, 1987 and Stanhill, 1990).

The actual yield decrease on a given farm after converting can be expected to depend on local conditions (soil, climate) as well as the farm managers skill and choice of crop rotation, stocking rate and manuring practice. This, in combination with the high number of yield determining factors and their important interactions, makes it difficult to predict the difference between organic and conventional crop yields from controlled experiments only. Also, 
the number of pairwise comparisons of organic and conventional cropping systems in experimental stations is limited which restricts the possibilities for generalization (Stanhill, 1990; Vereijken, 1994). It is therefore important to study crop yields under various practical conditions, but the problems of generalizing collected data to other growth conditions have to be considered. It is problematic to compare the yields on the same farm before and after conversion because of the differences between years. Differences in yearly climate and possible changes of farmers' skill and attitude resulting from collaboration with the researcher can interfere with the effects of farming system across the registration period.

Comparing yields from different organic and conventional farms is problematic owing to possible differences in, for instance, soil type, climate, and the farmer's skill. Lockeretz et al. (1981) and Steinmann (1983) selected carefully matched pairs of organic and conventional farms. While this facilitated a more fair comparison within each pair, the problems of explaining differences in organic conventional yield relations between pairs and years were not solved. The differences in measurable factors might be corrected in statistical models. We propose a statistical method to estimate yield differences between organic and conventional crops under a variety of conditions based on collected data from Danish mixed dairy farms.

The total crop yield on a farm is a combination of individual crop yields and the percentage area with each crop. These factors might again be influenced by the farm herd (fodder demand, manure supply). A simulation method for analyzing these interactions between herds and crops by systemic modelling (Sørensen \& Kristensen, 1992) combining herd and crop models is discussed.

\section{MATERIALS AND METHODS}

The data was obtained from 36 private dairy farms affiliated to the Danish Institute of Animal Science. The registration period occurred during the 4 years from 1 May 1989 until 30 April 1993. The goal of data collection was to describe the flow of energy, nutrients, and money on each farm. Information was collected at the farm level and at the herd and crop level. Data were collected, during biweekly visits, on fodder consumption over a 24-h period, stock assessments, farm purchases and sales, and the imputs into the crops. All registered inputs and crop yields were checked yearly against the farm's accounts. Fodder crop yields were net yields calculated from the animal production. A detailed description of each farm's production system and yield during the working years was presented in yearly publications (Østergaard, 1990, 1991; Kristensen \& Østergaard, 1992; Kristensen; 1993).

While the farms had dairy or beef cattle production as the main enterprise, they all had grain production. Seventeen of the farms met the Danish organic 
regulation prohibiting the use of chemically-produced fertilizers and pesticides. Non-organic fodder, only of Danish production, was limited to $15 \%$ and animal manure was applied from a maximum of 1.4 livestock units (LU) ha $^{-1}$ year $^{-1}$.

There were some differences regarding the type of land, crops and cattle within the two main groups (i.e. organic and conventional farming systems), Table 1. While the average number of cows per farm was nearly identical, the organic farms had slightly more land, a higher proportion of Jersey cows, and a minor production of fattening bull calves. The number of livestock units per hectare was therefore $40 \%$ greater on the conventional than on the organic farms. The area of permanent pasture was nearly identical for the two farming systems (8-11\%). The area with fodder beets and whole crop silage from small grains was higher on conventional farms, whereas the organic farms had more grass/clover in rotation including $9 \%$ alfalfa. The crops on the remaining area were different types of cereals (including about $10 \%$ winter cereals) and other cash crops such as potatoes and rape seed. The total area of crops with a long growing season was $80-85 \%$ in both groups.

Yields were analyzed at the farm level (excluding permanent grass) and separately for four types of crops: fodder beets, grass/clover in rotation (including alfalfa), spring sown grain, and winter grain. Grain includes legumes and mixtures of grain and legumes. The mixtures of spring barley and peas were often used on the organic farms to compensate for limited manure supply. Moreover, often the most weed infested parts of the spring sown grain crops under sown with grass/clover, which had low grain yield potential especially on the organic farms, were cut for whole crop silage. For these reasons only the yearly average yield of spring sown or winter grain crops and mixtures on each farm is analyzed when comparing the two systems. The harvested grain yield in $\mathrm{kg} \mathrm{ha}^{-1}$ was converted to roughage, measured in Scandinavian Feed Units (SFU) (1 kg grain * $1.3333=1 \mathrm{SFU}=12 \mathrm{MJ} \mathrm{ME})$.

The grass/clover crops of six farms had to be omitted from the analysis in one or more years because it was not possible to distinguish the area in rotation from permanent grassland with low yield potential. There were no incidents of wheat or fodder beets two years in a row on the same fields. Examples of typical crop rotations are given after Table 1.

Table 2 shows the input and yields in four crop types by soil types. Manure input in spring sown grain and fodder beets was higher on conventional farms than on organic farms, reflecting primarily the higher stocking rate on conventional farms (Table 1). The organic farms used more manure in winter grain and grass clover than the conventional farms that applied the largest amounts of fertilizer to these crops. Conventional crop yields were higher than organic in all crops with the relatively smallest difference in fodder beets. The effect of soil type appears to have been more important for conventional crops than organic but no simple relation between yield and input factors could be 
TABLE 1

Some characteristics for the analyzed project farms.

\begin{tabular}{|c|c|c|c|c|}
\hline \multirow{4}{*}{$\begin{array}{l}\text { System } \\
\text { Number of farms: } \\
\text { Distribution regarding } \\
\text { Soil type: sandy/irrigated sandy/clay } \\
\end{array}$} & \multicolumn{2}{|c|}{ Organic } & \multicolumn{2}{|c|}{ Conventional } \\
\hline & & \multicolumn{2}{|c|}{19} \\
\hline & \multicolumn{2}{|c|}{$3 / 6 / 8$} & \multicolumn{2}{|c|}{$8 / 9 / 2$} \\
\hline & \multicolumn{2}{|c|}{ Average (min.-max.) } & \multicolumn{2}{|c|}{ Average (min.-max.) } \\
\hline Area (ha) & 76 & $(25-181)$ & 63 & $(30-150)$ \\
\hline Permanent pasture $(\%)$ & 11 & $(1-40)$ & 8 & $(3-33)$ \\
\hline Rotation grass/clover or alfalfa ${ }^{\mathrm{b}}(\%)$ & 38 & $(25-67)$ & 26 & $(10-70)$ \\
\hline Fodder beets $(\%)$ & 3 & $(0-11)$ & 10 & $(5-29)$ \\
\hline Whole crop silage from small grains (\%) & 14 & $(1-38)$ & 16 & $(3-63)$ \\
\hline Small grain for harvest (\%) & 28 & $(15-50)$ & 32 & $(0-68)$ \\
\hline Other cash crops & 5 & $(0-20)$ & 7 & $(5-35)$ \\
\hline Cows per farm & 67 & $(21-170)$ & 60 & $(36-94)$ \\
\hline $\mathrm{LU} \mathrm{ha}^{-1 \mathrm{a}}$ & 1.06 & $(0.5-1.5)$ & 1.44 & $(0.6-2.3)$ \\
\hline
\end{tabular}

${ }^{a} 1$ livestock unit (LU) is equal to 1 dairy cow of approx. $550 \mathrm{~kg}$.

'Typical crop rotations:

5 years rotation with winter cereals and possibly fodder beets and potatoes on part of the land: Barley/peas/undersown with grass/clover or alfalfa, 2 years of grass/clover or alfalfa, winter or spring cereal, winter or spring cereal or fodder beets or potatoes.

4 year rotation with fodder beets on part of the land:

Barley/peas/undersown with grass/clover or alfalfa, 2 years of grass/clover or alfalfa, winter or spring cereal or fodder beets.

established from Table 2. The yield variation between years and farms (not shown) was almost the same in the organic and the conventional groups.

Table 3 shows average content of legumes and weeds in organic and conventional crops. While clover content was higher in organic grass/clover crops the average content of legumes in spring sown grain (including pure peas) was almost equal in the two systems. The only crop type with more than $5 \%$ average ground cover of weeds was the organic spring sown grain. Behind this average was a variation between $1-64 \%$ weeds with the highest content in grain and legume mixtures under sown with grass/clover. The levels of plant pathogens were modest.

Because of the imbalances and differences in soil type, irrigation, and climatic conditions it was not possible to compare the two systems directly. A statistical analysis was done to find significant determinators of the yields and to find the expected yield difference between organic and conventional farms, other things being equal. The goal was to establish a model that would facilitate predicting the expected yield loss if converting a given conventional farm to organic farming. 
TABLE 2

Average input and yield in four crop types by soil type, and average farm level yields in 36 organic and conventional mixed dairy farms, 1989-92. ${ }^{\text {a }}$

\begin{tabular}{|c|c|c|c|c|c|c|}
\hline $\begin{array}{l}\text { Crop type } \\
\text { Soil type }\end{array}$ & System & $\begin{array}{c}\text { Number of } \\
\text { of } \\
\text { crops }\end{array}$ & $\begin{array}{l}\text { Manure } \\
\mathrm{t} \mathrm{ha}^{-1}\end{array}$ & $\begin{array}{l}\text { Fertilizer } \\
\mathrm{kg} \mathrm{N} \mathrm{ha}^{-1}\end{array}$ & $\begin{array}{l}\text { Pesticides } \\
\text { Dkr. ha }{ }^{-1}\end{array}$ & $\begin{array}{l}\text { Yield }^{\mathrm{b}} \\
\text { SFU ha- }\end{array}$ \\
\hline $\begin{array}{l}\text { Spring sown grain } \\
\text { Clay }\end{array}$ & $\begin{array}{l}\text { Conventional } \\
\text { Organic }\end{array}$ & $\begin{array}{r}7 \\
32\end{array}$ & $\begin{array}{l}31 \\
23\end{array}$ & $\begin{array}{r}96 \\
0\end{array}$ & $\begin{array}{r}253 \\
-\end{array}$ & $\begin{array}{l}5700 \\
4400\end{array}$ \\
\hline $\begin{array}{l}\text { Not irrigated } \\
\text { sand }\end{array}$ & $\begin{array}{l}\text { Conventional } \\
\text { Organic }\end{array}$ & $\begin{array}{l}26 \\
12\end{array}$ & $\begin{array}{l}35 \\
27\end{array}$ & $\begin{array}{r}70 \\
0\end{array}$ & $\begin{aligned} 286 \\
-\end{aligned}$ & $\begin{array}{l}5300 \\
4600\end{array}$ \\
\hline Irrigated sand & $\begin{array}{l}\text { Conventional } \\
\text { Organic }\end{array}$ & $\begin{array}{l}31 \\
19\end{array}$ & $\begin{array}{l}31 \\
26\end{array}$ & $\begin{array}{r}62 \\
0\end{array}$ & $\begin{array}{r}316 \\
-\end{array}$ & $\begin{array}{l}5600 \\
3900\end{array}$ \\
\hline $\begin{array}{l}\text { Winter grain } \\
\text { Clay }\end{array}$ & $\begin{array}{l}\text { Conventional } \\
\text { Organic }\end{array}$ & $\begin{array}{r}4 \\
28\end{array}$ & $\begin{array}{r}32 \\
36\end{array}$ & $\begin{array}{r}190 \\
0\end{array}$ & $\begin{array}{r}725 \\
-\end{array}$ & $\begin{array}{r}10800 \\
6400\end{array}$ \\
\hline $\begin{array}{l}\text { Not irrigated } \\
\text { sand }\end{array}$ & $\begin{array}{l}\text { Conventional } \\
\text { Organic }\end{array}$ & $\begin{array}{r}18 \\
8\end{array}$ & $\begin{array}{l}19 \\
47\end{array}$ & $\begin{array}{r}164 \\
0\end{array}$ & 442 & $\begin{array}{l}7000 \\
4800\end{array}$ \\
\hline Irrigated sand & $\begin{array}{l}\text { Conventional } \\
\text { Organic }\end{array}$ & $\begin{array}{r}13 \\
8\end{array}$ & $\begin{array}{l}29 \\
31\end{array}$ & $\begin{array}{r}137 \\
0\end{array}$ & 739 & $\begin{array}{l}8400 \\
5000\end{array}$ \\
\hline $\begin{array}{l}\text { Fodder beets } \\
\text { Clay }\end{array}$ & $\begin{array}{l}\text { Conventional } \\
\text { Organic }\end{array}$ & $\begin{array}{r}7 \\
20\end{array}$ & $\begin{array}{l}85 \\
56\end{array}$ & $\begin{array}{r}137 \\
0\end{array}$ & $\begin{array}{r}1863 \\
-\end{array}$ & $\begin{array}{l}11300 \\
10900\end{array}$ \\
\hline $\begin{array}{l}\text { Not irrigated } \\
\text { sand }\end{array}$ & $\begin{array}{l}\text { Conventional } \\
\text { Organic }\end{array}$ & $\begin{array}{l}15 \\
12\end{array}$ & $\begin{array}{l}56 \\
58\end{array}$ & $\begin{array}{r}147 \\
0\end{array}$ & $\begin{array}{r}1938 \\
-\end{array}$ & $\begin{array}{r}10000 \\
9100\end{array}$ \\
\hline Irrigated sand & $\begin{array}{l}\text { Conventional } \\
\text { Organic }\end{array}$ & $\begin{array}{r}25 \\
6\end{array}$ & $\begin{array}{l}84 \\
65\end{array}$ & $\begin{array}{r}105 \\
0\end{array}$ & 1876 & $\begin{array}{r}11700 \\
8900\end{array}$ \\
\hline $\begin{array}{l}\text { Grass/clover, Alfalf } \\
\text { Clay }\end{array}$ & $\begin{array}{l}\text { Conventional } \\
\text { Organic }\end{array}$ & $\begin{array}{r}6 \\
32\end{array}$ & $\begin{array}{l}4 \\
8\end{array}$ & $\begin{array}{r}281 \\
0\end{array}$ & - & $\begin{array}{l}6800 \\
6000\end{array}$ \\
\hline $\begin{array}{l}\text { Not irrigated } \\
\text { sand }\end{array}$ & $\begin{array}{l}\text { Conventional } \\
\text { Organic }\end{array}$ & $\begin{array}{l}21 \\
12\end{array}$ & $\begin{array}{l}13 \\
17\end{array}$ & $\begin{array}{r}215 \\
0\end{array}$ & $\begin{array}{r}22 \\
-\end{array}$ & $\begin{array}{l}6200 \\
5400\end{array}$ \\
\hline Irrigated sand & $\begin{array}{l}\text { Conventional } \\
\text { Organic }\end{array}$ & $\begin{array}{l}31 \\
20\end{array}$ & $\begin{array}{l}10 \\
27\end{array}$ & $\begin{array}{r}215 \\
0\end{array}$ & $\begin{array}{l}20 \\
-\end{array}$ & $\begin{array}{l}7500 \\
5400\end{array}$ \\
\hline $\begin{array}{l}\text { Farm level average } \\
\text { all crops }\end{array}$ & $\begin{array}{l}\text { Conventional } \\
\text { Organic }\end{array}$ & $\begin{array}{l}19 \\
17\end{array}$ & $\begin{array}{l}31 \\
22\end{array}$ & $\begin{array}{r}148 \\
0\end{array}$ & $\begin{array}{r}440 \\
0\end{array}$ & $\begin{array}{l}6600 \\
5100\end{array}$ \\
\hline
\end{tabular}

${ }^{\mathrm{a}}$ Grass yields omitted for six farms because of lack of separate yield for rotation grass clover. Grain yields and farm level yield omitted for two conventional farms because of incomparably high proportion of cash crops (only $0.1 \mathrm{LU} \mathrm{ha}^{-1}$ ).

${ }^{\mathrm{b}}$ Scandinavian Feed Units (1 SFU $\left.=12 \mathrm{MJ} \mathrm{ME}\right)$.

'Weighted average per farm including crops not shown: Aftermath in rye grass under sown in grain crops, potatoes and rapeseed. 
TABLE 3

Average percentage of legumes, weeds, and crop pathogens in conventional (1990-92) and organic (1989-92) crops. Visual assessment of percent ground cover with legumes and weeds and leaf cover with pathogens (in grain crops primarily mildew, in fodder beets primarily virus yellow).

\begin{tabular}{lcccccccc}
\hline \multirow{2}{*}{ System } & \multicolumn{3}{c}{ Conventional } & & \multicolumn{3}{c}{ Organic } \\
\cline { 1 - 1 } Crop & Legumes & Weeds & Pathogens & & Legumes & Weeds & Pathogens $^{\text {a }}$ \\
\hline Spring sown grain & 8 & 1 & 0.5 & & 13 & 13 & 2 \\
Winter grain & 0 & 1 & 2 & & 2 & 5 & 3 \\
Fodder beets & - & 2 & 21 & & - & 3 & 39 \\
Grass clover & 21 & 2 & - & & 50 & 3 & - \\
\hline
\end{tabular}

apure cereals.

The statistical analysis was done at farm and crop level using multiple linear regression methods (GLM procedure in SAS, Anonymous, 1990). Since individual crop yields on the same farm were not independent, the effect of farming system was tested in a model with one yield for each farm. Thus, an area weighted crop yield average over all years was calculated for each farm expressing both yield levels and area of the individual crops (Model I in Table 5; Why PY and Soil Type were included in the final version of this farm level test is explained later).

To break down this overall systemic difference, the effects of system, year, crop type, soil type, climatic region, and interactions between system and class variables were tested in a model with one yield per crop type per farm and year (Model II). The variable soil type had three levels: sand, irrigated sand and clay.

With the aim of finding a single parameter to describe the difference in climate and soil type between farms and years, farm specific potential yields (PY) in Hkg DM ha-1 were calculated for each crop and year with the simulation model WATCROS (Aslyng \& Hansen, 1982). The model used daily values of air temperature, global radiation, and precipitation which were calculated for each farm from registrations on the two-five nearest meteorological stations by $\mathrm{H}$. Mikkelsen, Department of Land Use, after principles described in Mikkelsen (1990). The PY can thus be defined as yields which are only limited by temperature, radiation and water supply.

For each crop PY values were calculated with and without irrigation. The drying of the soil was calculated by the model from information on plant utilizable water in the root zone estimated from average soil texture analysis on each farm. For grass, for example, on sandy soils with $0-5 \%$ clay and on clay soils with $10-15 \%$ clay, the estimates were $60 \mathrm{~mm}$ and $150 \mathrm{~mm}$ plant available soil water, respectively. Most of the farms did not have sufficient 
irrigation capacity to match the high daily potential evapotranspiration or they were irrigating too late when the plants were already drought stressed. To compensate for this in the model, the PY on irrigated soils was calculated as $0.75 \mathrm{PY}$ irrigated $+0.25 \mathrm{PY}$ unirrigated. Table 4 shows examples of PY of grass and spring sown cereals on three farms. While PY on the irrigated sandy soil was almost constant over the four years there were large variations on the unirrigated soils. A severe drought in 1992 reduced PY on both sand and clay to the lowest levels in the four-year period. Also 1989 was a dry year on the clay soil farm situated in the eastern part of Denmark. In average (not shown) the organic farms had warmer and more dry climate than the conventional with more farms situated in the eastern regions of Denmark on clay soils.

The data set was analyzed using the PY values as a regression variable instead of the class variables year, soil type, and region (Model III). The residuals from this model were subsequently tested against year, soil type and region. Since PY takes the soils water supply into account, soil type in this test had only two levels: clay and sand.

The resulting model was thereafter used to find crop specific regression equations by analysis of the four crops separately. Finally these regression equations were used to predict the yield difference under standardized growth conditions (average PY).

\section{RESULTS}

The overall analysis using one observation per farm showed significant difference $(\mathrm{P}<0.001)$ between organic and conventional average crop yields (Model I, Table 5). The organic farms had 24\% lower yield per ha than conventional (5300 SFU ha ${ }^{-1}$ vs. $\left.7000 \mathrm{SFU} \mathrm{ha}^{-1}\right)$. In model II $($ Yield $=$ System, Crop Type, Year, Soil Type, Region and first order interactions between System and Crop Type, Soil Type and Year) an analysis with one yield per

TABLE 4

Farm specific potential yields of spring sown grain and grass. Variation over four years, 1989-92. (Hkg DM ha' ${ }^{-1}$ (selected examples).

\begin{tabular}{|c|c|c|c|c|c|c|}
\hline & \multicolumn{2}{|c|}{ Clay $(26-7)$} & \multicolumn{2}{|c|}{ Sand (70-9) } & \multicolumn{2}{|c|}{ Irrigated sand (34-8) } \\
\hline & Grain & Grass & Grain & Grass & Grain & Grass \\
\hline 1989 & 122 & 101 & 142 & 129 & 153 & 184 \\
\hline 1990 & 165 & 148 & 145 & 111 & 155 & 192 \\
\hline 1991 & 159 & 135 & 137 & 100 & 155 & 192 \\
\hline 1992 & 102 & 87 & 80 & 82 & 139 & 186 \\
\hline
\end{tabular}


crop per farm and year showed significant differences between years, soil types and regions with first order interactions between systems and crop, year, and soil type, respectively (it was not possible to test possible interaction between system and region). Because of the interactions this model was considered to be unsuitable for predicting yield differences on the basis of the unbalanced data set. Therefore the models with PY were developed.

The statistical Model III (yield = system, crop type, PY (nested within crop type) and interaction between PY and system) used PY instead of year, soil type, and region and explained the variation almost as well as Model II $\left(\mathrm{R}^{2}\right.$

\section{TABLE 5}

Linear statistical models of four years crop yields $\left(100 \mathrm{SFU} \mathrm{ha}{ }^{-1}\right)$ on organic and conventional farms.

\footnotetext{
PY $=$ Potential yield in Hkg DM ha ${ }^{-1}$

System $=$ Organic, conventional

Crop type $=$ Spring sown grain, winter grain, fodder beets, grass/clover in rotation

Year $=1989,1990,1991,1992$

Soil type = Clay, sand (Model I, III, IV), clay, sand, irrigated sand (Model II)

Region $=$ Five geographical regions of Denmark

$*, * *, * * *$ indicates significance levels of $0.05,0.01$, and 0.001 , respectively.

".-" indicates not significant predictors omitted from the final models.

"ns" indicates not significant predictors included because of significant interactions with other predictors.
}

Model I: $\quad$ One observation per farm (4 years weighted average of all crops).

Model II-IV: One observation per crop and farm per year.

\begin{tabular}{|c|c|c|c|c|}
\hline Model & I & II & III & IV \\
\hline System & $* * *$ & $* * *$ & ns & $\mathrm{ns}$ \\
\hline Crop type & - & $* * *$ & ** & $* *$ \\
\hline Year & - & $* * *$ & - & - \\
\hline Soil type & $*$ & $* * *$ & - & $* * *$ \\
\hline Region & - & $* *$ & - & - \\
\hline System * crop type & - & ** & ns & $\mathrm{ns}$ \\
\hline System * year & - & * & - & - \\
\hline System * soil type & - & * & - & - \\
\hline PY (crop type) ${ }^{\mathrm{a}}$ & ns & - & $* * *$ & $* * *$ \\
\hline System * PY (crop type) & - & - & * & * \\
\hline D.F. model & 3 & 21 & 15 & 16 \\
\hline D.F. error & 32 & 397 & 403 & 402 \\
\hline $\mathrm{R}$-square & 0.53 & 0.73 & 0.71 & 0.72 \\
\hline MSE & 8.8 & 14.8 & 15.1 & 14.8 \\
\hline
\end{tabular}

${ }^{a}$ D.F. PY (Crop Type $)=4$ in model III and IV because of nesting. 
$=0.71$, Table 5) with a mean square error (MSE) of 15.1 against 14.8. Since the regression variable PY (crop type), D.F. $=4$, could thus replace three class variables and thereby reduce the model's degree of freedom from 21 to 15 Model III was considered superior to Model II. A test of residuals from Model III against the class variables, however, showed a significant effect of soil type (clay vs. sand, only), but no interaction with system. Thus, PY did not totally correct for the soil type induced variation. This class variable was therefore included in Model IV, which decreased MSE to 14.8. (For the same reasons soil type and PY (average per farm) were included in the final version of the farm level test, i.e. Model I). Model III and IV included a significant interaction between systems and PY. Model IV was then used to establish regression equations for each crop separately. The interaction (system * PY) was included in all four crop models but was not significant for grass clover and fodder beets.

Table 6 shows the different regression coefficients of PY for organic and conventional crops. For all crops the predicted yields will increase more on conventional farms than on organic farms when PY is increased. The difference is largest for winter cereals, where organic crops can be expected to rise $1300 \mathrm{SFU}$ per $100 \mathrm{Hkg}$ DM increase in PY, while predicted conventional crop yields rise $3100 \mathrm{SFU}$. The grass yields were less dependent on PY than the other crops with regression coefficients of 0.1 and 0.16 .

A statistical test showed no significant difference between PY averaged over the farms within four geographic regions. The PY was more dependant on soil type and irrigation whereas the small climatic differences between the regions of Denmark were of minor importance. Therefore, average PY for three soil types (clay, sand, and irrigated sand) were calculated for each crop type using PY from all four years on the clay and sandy soil study farms, respectively. The average PY values were then used to predict organic and conventional crop yields from the regression equations in Table 6. The predicted yield

TABLE 6

Regression equations for predicting organic and conventional crop yields (100 SFU ha-1) as a function of soil type (clay vs. sand), and simulated potential yield (Hkg DM ha ${ }^{-1}$ ).

\begin{tabular}{|c|c|c|c|c|c|c|c|}
\hline & & & $\begin{array}{l}\text { System } \\
\text { conv. }\end{array}$ & & $\begin{array}{l}\text { Soil type } \\
\text { clay }\end{array}$ & & $\begin{array}{l}\text { Potential Yield (PY) } \\
\text { Org. I Conv. }\end{array}$ \\
\hline Spring sown grain $=$ & 13 & - & 3 & + & 3 & + & $(0.21 * \mathrm{PY} \mid 0.33 * \mathrm{PY})$ \\
\hline Winter grain $=$ & 27 & - & 5 & + & 14 & + & (0.13*PY $\mid 0.31 * \mathrm{PY})$ \\
\hline Fodder beets $=$ & 37 & - & 22 & + & 7 & + & $(0.30 * \mathrm{PY} \mid 0.49 * \mathrm{PY})$ \\
\hline Grass clover $=$ & 41 & + & 2 & + & 8 & + & $(0.10 * \mathrm{PY} \mid 0.16 * \mathrm{PY})$ \\
\hline
\end{tabular}


(in $100 \mathrm{SFU} \mathrm{ha} \mathrm{h}^{-1}$ ) of organic spring sown grain on sand and clay soils respectively were thus calculated as $13+0.21 * \mathrm{PY}$ and $13+3+0.21 * \mathrm{PY}$ respectively while the corresponding conventional yields were: $13-3+0.33 * \mathrm{PY}$ and $13-3+3+0.33 * \mathrm{PY}$. The values used for PY are shown in Table 7: 136 on clay soil in both systems and 149 and 110 for spring sown grain on sandy soils with and without irrigation.

Table 7 shows that predicted differences between organic and conventional crops were larger on irrigated sandy soils where PY was highest. This was especially true for grain crops. While predicted conventional winter cereal yield on irrigated sand was $1700 \mathrm{SFU}$ ha $^{-1}$ higher than on unirrigated sand, the same difference was only $800 \mathrm{SFU} \mathrm{ha}{ }^{-1}$ for organic winter grain crop. Though PY was lower on clay than on irrigated sand, predicted spring sown grain yields were the same and winter cereal yield higher on clay soil in both systems.

TABLE 7

Average potential yields (PY, Hkg DM ha-1) and predicted yields ( $\mathrm{SFU} \mathrm{ha} \mathrm{h}^{-1}$ ) of organic and conventional crops on three soil types.

\begin{tabular}{|c|c|c|c|c|c|c|c|}
\hline \multirow{2}{*}{ Crop } & \multirow{2}{*}{$\begin{array}{l}\text { Soil type } \\
\text { System }\end{array}$} & \multicolumn{2}{|c|}{ Clay } & \multicolumn{2}{|c|}{ Sand } & \multicolumn{2}{|c|}{ Irrigated sand } \\
\hline & & PY & Yield & PY & Yield & PY & Yield \\
\hline \multirow{5}{*}{$\begin{array}{l}\text { Spring sown } \\
\text { grain }\end{array}$} & Organic & 136 & 4400 & 110 & 3600 & 149 & 4400 \\
\hline & Conventional & 136 & 5700 & 110 & 4600 & 149 & 5900 \\
\hline & Difference & & 1300 & & 1000 & & 1500 \\
\hline & Difference $\%$ of & & 27 & & & & 25 \\
\hline & & & & & 22 & & $2 J$ \\
\hline \multirow{5}{*}{ Winter cereals } & Organic & 179 & 6500 & 146 & 4600 & 202 & 5400 \\
\hline & Conventional & 179 & 9300 & 146 & 6800 & 202 & 8500 \\
\hline & Difference & & 2800 & & 2200 & & 3100 \\
\hline & Difference $\%$ of & & & & & & \\
\hline & Conventional & & 30 & & 32 & & 36 \\
\hline \multirow[t]{5}{*}{ Fodder beets } & Organic & 204 & 10500 & 179 & 9000 & 200 & 9700 \\
\hline & Conventional & 204 & 12200 & 179 & 10200 & 200 & 11300 \\
\hline & Difference & & 1700 & & 1200 & & 1600 \\
\hline & Difference $\%$ of & & & & & & \\
\hline & Conventional & & 14 & & 12 & & 14 \\
\hline \multirow[t]{5}{*}{ Grass/clover } & Organic & 114 & 6100 & 109 & 5200 & 177 & 5900 \\
\hline & Conventional & 114 & 6900 & 109 & 6000 & 177 & 7100 \\
\hline & Difference & & 800 & & 800 & & 1200 \\
\hline & Difference $\%$ of & & & & & & \\
\hline & Conventional & & 12 & & 13 & & 17 \\
\hline
\end{tabular}




\section{DISCUSSION}

\section{Prediction of conventional crop yields}

The predicted conventional crop yields and the differences between soil types are comparable with field trial gross yields on the Danish Institute of Crop and Soil Science experimental stations (Olesen, 1990-1993). When comparing experimentally-derived gross yields with the fodder crop net yields in this study roughly $20 \%$ loss due to conservation and selection under grazing should be allowed. The predicted yield increase from irrigation on sandy soils is lower than expected yield increases on coarse sanded soils with only $60 \mathrm{~mm}$ root zone capacity. However, since our soil type group includes sandy soils with higher root zone capacity and most of the farms' irrigation capacity was insufficient in periods with high requirements the results were acceptable.

Winter grain yields include both rye and wheat and only four conventional crops were on clay soil. Rye was often grown with low inputs partially reflecting lower yield expectations because of poor growth conditions (coarse sanded soils, no irrigation or secondary place in the crop rotation). Therefore, the prediction model for winter grain yield is less reliable, which is acceptable only because the area with winter grain on dairy farms normally is limited ( $10 \%$ on average in this study).

Crop yields were influenced by farming system, soil type, and climate. Simulated PY can be considered as an index of climatic growth conditions which facilitates a better interpretation of the data than would be possible with the class variables, soil type, region and year, and their interactions with cropping system (see below). However, PY did not explain all variation due to difference in soil type (sand vs. clay, only). The reason might be that PY derived from the WATCROS simulation model only corrects for differences in water supply but not soil fertility. The remaining variation between sand and clay soil crop yields thus could be caused by the generally lower content of nutrients in sandy soils compared with clay soils.

\section{Organic versus conventional crop yields}

The lower regression coefficients for PY on the organic crops suggest that their yields increase less than conventional crops when climatic conditions for dry matter production, including water supply, get better. Other yield determining factors seem to be more important for the organic crops. Lockeretz et al. (1981) also found the yield difference between organic and conventional maize on selected farms to depend on "the growing conditions in the particular year as measured by the deviation of the countrywide corn yield from the 10 years 
county average". In a number of comparative experiments reviewed by Stanhill (1990) interactions between growth season (conventional yield level) and relative organic yields were assumed to be caused by climatic variation. No climatic indicators were, however, shown to be correlated with the actual yields. The use of simulated PY in this study offers a method to quantify these differences in climate and soil water capacity between farms and years.

The interaction between PY and system causes predicted organic and conventional yields to differ more on irrigated sandy soils (Table 7). The higher yield potential on these soils is better matched by conventional crops than organic, probably because the organic crops lack nutrients to respond to the increased water supply. Besides the general higher nitrogen supply to the conventional crops (see Table 2), they were often also supplied with mineral $\mathrm{P}, \mathrm{K}$ and micro-nutrients. These suggestions of nutrient deficiencies on organic sandy soil farms and the apparent interaction between PY and system need to be verified through future research. Within the group of irrigating farms there was a small, not significant tendency towards a lower irrigation capacity on the organic farms, but it was not possible to estimate the precise effect of this on the PY.

The relatively lowest yield differences were found in the fodder crops. Since these were registered as net yields, conservation losses and differences in animal feed efficiency ratio might level out some of the gross yield differences.

The organic grass/clover crops included alfalfa and had on average nearly $50 \%$ legumes. The roughly $1000 \mathrm{SFU} \mathrm{ha}^{-1}(12-17 \%)$ lower yield on organic farms is not surprising considering the more than $200 \mathrm{~kg}$ fertilizer $\mathrm{N}$ applied to the conventional crops. In a more detailed study of the grass clover management on the same farms, Kristensen (1994) concluded that the grazing management was good and with no systematic differences between organic and conventional farms. A recent Danish grazing trial has shown a yield increase of only 1-6 SFU kg N ${ }^{-1}$ depending on stocking rate (Aaes \& Kristensen, 1993). The development of a high percentage of clover $(45 \%)$ in the non-fertilized plots was believed to be an important explanation for the relatively low $\mathrm{N}$ response in the fertilized plots.

The small areas with organic fodder beets were normally given high priority with manure supply, establishment and weeding (Tables 2 and 3 ) and because of the long growth season this crop can utilize nitrogen mineralized through the summer period. To protect against virus yellow the conventional fodder beets were normally treated with insecticides aimed at controlling the peach potato aphids. The percentage of beet top infected by virus was lower in the conventional beet crops than in the organic.

The crop level differences were largest for winter grain followed by spring sown grain which is in agreement with Stanhill $(1990 ; 10-20 \%$ lower yield in organic grain crops versus $9 \%$ in average for organic crops) and Mühlebach 
\& Näf (1990; 25\% lower wheat yield versus 20\% in barley). Both organic grain types often lacked $\mathrm{N}$ but, compared to conventional crops, the difference in $\mathrm{N}$ supply was largest for winter grains. While the conventional farms grew short wheat varieties for fodder, the organic farms most often grow high protein bread varieties, which according to Danish variety trials, yield roughly $15 \%$ less than the best fodder types.

The organic spring sown grain crops were often mixtures of barley and peas either because of lack of manure or in the hope of increasing protein content and digestibility of the crop. In many of these mixtures, however, the peas contributed very little to the yield, among other reasons because of too shallow seeding. Since the barley most often was not able to compensate by increased tillering, yields were probably reduced considerably.

The difference in manure supply per ha and the fertilizer application shown in Table 2 indicate the generally much higher $\mathrm{N}$ supply to conventional grain crops compared to organic. On many of the organic farms one or two crops in the rotation (mainly spring sown grain and fodder beets) were supplied less $\mathrm{N}$ than they removed (Halberg et al., 1995). This positive net utilization of soil $\mathrm{N}$ mineralized during the growing season was an important explanation of lower $\mathrm{N}$ surplus and loss on the organic farms. Since total $\mathrm{N}$ supply in manure and fertilizer to the conventional crops were not lower than Danish standard levels (Pedersen, 1992), their yields were probably only marginally affected by differences in $\mathrm{N}$ supply. For this reason and because of possible interactions between many yield determining factors any simple correlation between crop yields and nitrogen levels is unlikely to be found in this material. The difference in $\mathrm{N}$ levels between organic and conventional crops was, however, not coincidental, but reflects the Danish organic farming rules limiting stocking rate and manure supply.

There were large variations in the weed and pathogen levels but on average only weeds in spring sown grains were found to be a larger problem in organic crops compared with conventional (Table 2 and Holm, 1994). The levels of pests and pathogens in the organic crops were on average comparable with the conventional crops that were normally treated with pesticides. Low grain plant density with only 400 tillers $\mathrm{m}^{-2}$ together with the lower $\mathrm{N}$ supply probably give limited pest infection conditions in organic crops. Interactions between plant density, fertilizer levels and level of plant pathogens have been found in experiments (Bødker et al., 1994).

Compared to Danish experimentally-derived fertilizer and pesticide yield responses in barley in the years 1982-92 (Pedersen, 1992) the yield difference found in this investigation seems modest. We suggest that the main reasons for that were: Higher $\mathrm{N}$ mineralization on organic soils due to a larger grass clover area in the crop rotation, increased utilization of mineralized $\mathrm{N}$ from soil and manure in organic crops, and interactions between $\mathrm{N}$ supply levels and crop yield losses from plant pests. 
Thus, the above mentioned interactions, together with the yearly and spatial variation in fungicide and insecticide yield response in Denmark (Pedersen, 1992, 1993) and problems with assessing the effects of different crop rotations on plant nutrition and crop health, makes it difficult to predict organic crop yield losses from experimental knowledge alone. On the other hand the interpretation of unbalanced collected data raises many questions that can only be thoroughly researched in well designed experiments. This again calls for a better integration of discipline oriented and systems oriented research, especially when dealing with predictive models in agronomy as stressed by Sebillotte (1994). Thus it is hoped that organic grain crop yields can be increased by researching the effects of, for instance, seed rate, timing of soil preparation especially after grass/clover and deep litter manure management in close collaboration with commercial farmers.

\section{Farm level results and generalization}

The $24 \%$ lower farm level crop yield (LS MEANS) on organic farms results from a combination of lower yields in individual crops and different partitioning of the cropped area. The organic farms thus had a smaller percentage of the area with the highest yielding crop, fodder beets (Table 1), mainly because of limited capacities for weeding. Limited nitrogen $(\mathrm{N})$ resources were an important determinant of organic grain area and therefore the higher grass clover area on organic farms was not coincidental. Therefore, the farm level difference could not have been predicted entirely from knowledge on individual crop level. The farmer's own logic, when managing the whole farm, has to be taken into consideration (Sørensen \& Kristensen, 1992; Beranger \& Vissac, 1994; Sebillotte, 1994), for instance by systems research based on farm studies.

The predictions shown here apply to the years 1989-92 because the PYs used were calculated for these years. To generalize the results further it is suggested to use a 30 year normal PY calculated for different soil types as an average of individual simulations of PY for the last 30 years. Such simulations would also facilitate an evaluation of the variation between years in the predicted organic-conventional yield differences. Generalization of the model predictions should be restricted to estimation of the yield loss when converting to organic farming on different soil types and climatic conditions in Denmark. It is not believed that the statistical model can be used to predict actual yields on other farms. The large standard error of prediction for individual cases (1100-1200 SFU ha ${ }^{-1}$ (not shown)) gives too large confidence intervals, reflecting that much of the yield variation between farms was not accounted for by the model. Moreover, the parameter estimates from this type of statistical modelling are sensible to changes in individual cases. One organic 
sandy soil farm had almost half of the land classified as clay soil. Thus, recalculating the prediction model with this farm in the clay soil group lowered the predicted sandy soil yields, but the difference between the systems remained almost unchanged. The method itself might be applicable in other crops and other geographic regions if sufficient climatic data and crop simulation models are available.

The data do not allow conclusions concerning the existence of any relations between organic crop yields and the number of years after conversion. While some of the clay soil farms had been organic (biodynamic) for more than 25 years, most of the organic farms on sandy soils were converted 1-5 years before the study period. Future work following some of these farms will show if the estimated yield functions apply after a longer period and if the proposed nutrient deficiencies can be tackled.

The predictions of relative yield loss are of interest when analyzing economics of organic farming, for instance for deciding subsidy levels (Anon., 1992). We do not find it suitable here to make a separate economic evaluation of the crop production, since cash crop production was closely linked with the dairy production and the availability of manpower. The net revenue of cash crops and the internal prices of fodder crops are shown in the yearly farm reports (Østergaard, 1990, 1991; Kristensen \& Østergaard, 1992; Kristensen, 1993). The crop yield results together with an analysis of the herd performances (Kristensen, 1994) might facilitate simulation of the conversion of specific farms. By use of a computer model integrating crop and herd production different strategies for conversion of a dairy farm and different crop rotations and feeding strategies could be evaluated in technical and economic terms a farm level (Hansen, 1990). Limits on the percentage area with different crops would be necessary to secure realistic generalization from this type of systemic modelling. Besides the effect of limited $\mathrm{N}$ supply, governing total organic grain area, the partition between winter and spring sown grain have to be restricted. The higher yield of organic winter grain compared to spring sown, found in the results, was partly an effect of higher manure supply and the best places in crop rotation.

Recently the results have been used to calculate energy efficiency in conventional and organic crops (Halberg et al., 1994) and it is expected that the modelling of data from farm studies can contribute to highlighting relations between the production intensity on one side and resource use and environmental impacts of farming on the other.

\section{ACKNOWLEDGEMENTS}

The authors wish to thank Dr. H. Mikkelsen, Department of Land Use, Danish Institute of Crop and Soil Science, for supplying the climatic data input to the simulation model. 


\section{References}

Aaes, O. \& Kristensen, E.S. (1993). Dairy production from grass-white clover systems: The effect of nitrogen fertilizer, grazing intensity and supplement feeding at continuous stocking. Gráss \& Forage Sciences (submitted).

Anonymous (1990). SAS/STAT User's Guide, Version 6, 4th edn. SAS Institute Inc.

Anonymous (1992). Rapport om Økonomien ved Omlagning til фkologisk Jordbrug. (Economic consequences of converting to organic farming). Ministry of Agriculture.

Aslyng, H.C. \& Hansen, S. (1982). Water Balance and Crop Production Simulation. Hydrotechnical Laboratory. The Royal Vet. Agric. Univ. Copenhagen.

Beranger, C. \& Vissac, B. (1994). An holistic approach to livestock farming systems. Theoretical and methodological aspects. In The Study of Livestock Farming Systems in a Research and Development Framework. (A. Gibon \& J.C. Flamant, eds.), EAAP Publ. 26.

Bødker, L., Nistrup Jørgensen, L. \& Secher, B.J.M. (1994). Epidemiological development of mildew under influence of different growth factors. 11. Danske plantevarnskonference. pp. 29-46.

Halberg, N.,Kristensen, I. Sillebak \& Kristensen, E. Steen (1995). Nitrogen turnover on organic and conventional mixed farms. Journal of Environmental and Agricultural Ethics, 8, 30-51.

Halberg, N., Kristensen, E. Steen \& Refsgaard, K. (1994). Energy use in conventional and organic crops. Systemic modelling of data from farm studies. Communications from Int. Symp. SystemsOriented Research in Agriculture and Rural Development. Montpellier, France, 21-25 November, pp. 360-365.

Hansen, J.P. (1990). An integrated decision support system for planning of feed supply and land use on the dairy farm. In Integrated Decision Support Systems in Agriculturé. Successful Practical Applications (F. Kuhlman, ed.), Proc. 3rd Int. Congr. Computer Tech., pp. 182-191.

Holm, S. (1994). Sygdomme og skadedyr i økologisk planteavl. (Pests and pathogens in organic crop production). Natl. Inst. Plant Sci. Report No. 17.

Kristensen, T. (1993). Studier i kvægproduktionssystemer. (Studies in cattle production systems). Beretning 722. National Institute of Animal Science; Denmark.

Kristensen, T., Vaarst, M. \& Kristensen, E. Steen (1994). Analysis of the production in Danish organic and conventional dairy herds. Paper Presented at 10th IFOAM Conference; Christchurch, New Zealand, 11-16 December.

Kristensen, T. \& Østergaard, V. (1992). Studier i kvægproduktionssystemer. (Studies in cattle production systems). Beretning 714. National Institute of Animal Science, DK.

Lockeretz, W., Shearer, G. \& Kohnl, D.H. (1981). Organic farming in the corn belt. Science, 211, 540-547.

Mikkelsen, H.E. (1990). Beregning af klimanormaler til kvadratnet for nitratmålinger. Normaler for nedbør, lufttemperatur, jordtemperatur og potential fordampning. (Calculation of standard climate values). AJMET, Arbejdsnotat No. 11.

Mühlebach, J. \& Näf, E. (1990). Die wettbewerbsfähigkeit des biologischen landbaus. Schrittenreihe der Eidgenössische Forschnungsanstalt für Betriebswirtschaft und Landtechnik; Tänikon.

Olesen, J.E. (1990, 1991, 1992, 1993). Jordbrugsmeteorologisk årsoversigt (annual agrometerological overview) Beretning S2055, Beretning S2130, Beretning S2202, SP Rapport 10, Statens Planteavlsfors $\emptyset \mathrm{g}$. Natl. Inst. of Crop and Soil Science.

Pedersen, C. Aa. (1992, 1993). Oversigt over landsforsфgene. (Local field trials organized by the farmers unions, published yearly).

Sebillotte, M. (1994). Analyzing farming and cropping systems and their effects. Some operative aspects. In Systems Studies in Agriculture and Rural Development (J. Brossier, L. de Bonneval \& E. Landais, eds.), pp. 273-290. INRA Editions; Paris.

Stanhill, G. (1990). The comparative productivity of organic agriculture. Agriculture, Ecosystems and Environment, 30, 1-26.

Steinmann, R. (1983). Der Biologische Landbau-ein Betriebwirtschaftlicher vergleich. Schrittenreihe der Eidgenössische Forschnungsanstalt für Betriebswirtschaft und Landtechnik (19); Tänikon.

Sørensen, J.T. \& Kristensen, E. Steen (1992). Systemic modelling: A Research methodology in livestock farming. In Global Appraisal of Livestock Farming Systems and Study of Their Organizational Levels (A. Gibon \& A. Matheron, eds.), pp. 45-57; Luxembourg. 
Wagstaff, H. (1987). Husbandry methods and farm systems in industrialised countries which use lower levels of external inputs: A review. Agriculture, Ecosystems and Environment, 19, 1-27.

Vereijken, P. (1994). 1. Designing prototypes progress. Report No. 20 of Research Network on Integrated and Ecological Arable Farming Systems for EU and Associated Countries (concerted action AIR3-CT920755).

Østergaard, V. (1990, 1991). Studier i kvægproduktionssystemer. (Studies in cattle production systems). Beretning 681, Beretning 699, National Institute of Animal Science, Denmark.

(Received 24 March 1995; accepted 27 October 1995) 